\title{
TRANSFORMATION OF THE MIGRATION SITUATION IN THE OLD AND NEW BORDERLANDS
}

\author{
Dmitriy P. Maevskiy \\ Omsk State Technical University, Omsk, Russian Federation
}

\begin{abstract}
The work is devoted to the assessment of the migration situation in the regions of the old and new borderlands of the Russian Federation in the period of 2008 and 2017. The use of methods of comparative analysis of migration processes in the border regions allowed differentiating and generalizing the migration flows by certain types of population migration exchange. The results of the research were obtained on the basis of generalization of statistical data and identification of the peculiarities of the transformation of the migration situation in the border regions for 2008 and 2017.

Studies have shown that the overall migration increase in the regions of the old borderland in 2008 was characterized by a negative value. All subjects of the old borderland in 2008 were attractive for foreign migrants. Positive migration increase was noted due to international migration in all the territories. The migratory situation in 2017 in the regions of the old borderland has changed: the number of regions where the total migration increase was positive has drastically decreased.

The internal migration in the regions of the new borderland was characterized by an outflow of the population, which compensated by 2.3 times the superior migration growth of international migration. By 2017, the number of subjects in the group of new border regions, where a positive migration increase was observed, decreased.

Based on the analysis of the structure of migration flows in the two groups of border regions, past and current characteristics of migration trends were identified. It is shown that constant population transformation takes place in the border area due to changes in the parameters and direction of the migration movement. Migration growth as a source of replenishment of the population of border territories in one period can be transformed into outflow in another period. The regions that are permanent migrant recipients and whose population is accumulated due to both domestic and international migration are identified.

The problem of population loss in a number of border regions due to migration processes entailing geopolitical and other risks is identified.

Key words: cross-border space, migration growth, internal migration, international migration, old border regions, new border regions.

Citation. Maevskiy D.P. Transformation of the Migration Situation in the Old and New Borderlands. Vestnik Volgogradskogo gosudarstvennogo universiteta. Seriya 3, Ekonomika. Ekologiya [Science Journal of Volgograd State University. Global Economic System], 2018, vol. 20, no. 4, pp. 55-64. (in Russian). DOI: https://doi.org/10.15688/ jvolsu3.2018.4.6
\end{abstract}

УДК 331:314.7(470+571)

Дата поступления статьи: 05.09.2018

ББК 65.9 (2Рoc) 240.7 Дата принятия статьи: 26.10.2018

\section{ТРАНСФОРМАЦИЯ МИГРАЦИОННОЙ СИТУАЦИИ В СТАРОМ И НОВОМ ПРИГРАНИЧЬЕ}

\author{
Дмитрий Павлович Маевский \\ Омский государственный технический университет, г. Омск, Российская Федерация
}

Аннотация. Работа посвящена оценке миграционной ситуации в регионах старого и нового приграничья Российской Федерации в период 2008 и 2017 годов. Применение методов сравнительного анализа миграционных процессов в приграничных регионах позволило дифференцировать и обобщить миграционные потоки по отдельным видам миграционного обмена населением. Результаты исследования получены на 
основе обобщения статистических данных и выявления особенностей трансформации миграционной ситуации в приграничных регионах за 2008 и 2017 годы.

Исследования показали, что общий миграционный прирост регионов старого приграничья в 2008 г. характеризовался отрицательной величиной. Все субъекты старого приграничья в 2008 г. были привлекательны для переселения туда внешних мигрантов. Во всех территориях отмечен положительный миграционный прирост за счет международной миграции. Миграционная ситуация в 2017 г. в регионах старого приграничья изменилась: резко сократилось число регионов, в которых общий миграционный прирост являлся положительным.

Внутрироссийский миграционный обмен в регионах нового приграничья характеризовался оттоком населения, который в 2,3 раза компенсировал превосходящий миграционный прирост международной миграции. К 2017 г. в группе новых приграничных регионов уменьшилось число субъектов, где наблюдался положительный миграционный прирост.

На основе анализа структуры миграционных потоков в двух группах приграничных регионов были выявлены прошлые и современные характеристики миграционных трендов. Показано, что в приграничном пространстве происходят постоянные трансформации численности населения за счет изменения параметров и направления миграционного движения. Миграционный прирост как источник пополнения населения приграничных территорий в один период может трансформироваться в отток в другой период. Выявлены регионы, являющиеся постоянными миграционными реципиентами, население которых аккумулируется за счет и внутрироссийской, и международной миграции.

Обозначена проблема утраты населения в ряде приграничных регионов за счет миграционных процессов, влекущая в перспективе геополитические и иные риски.

Ключевые слова: приграничное пространство, миграционный прирост, внутрироссийская миграция, международная миграция, старые приграничные регионы, новые приграничные регионы.

Цитирование. Маевский Д. П. Трансформация миграционной ситуации в старом и новом приграничье // Вестник Волгоградского государственного университета. Серия 3, Экономика. Экология. - 2018. - Т. 20 , № 4. - C. 55-64. - DOI: https://doi.org/10.15688/jvolsu3.2018.4.6

Общим местом в исследованиях приграничного пространства России являются масштабы страны, протяженность самой границы, рекордное число граничащих государств. Вместе с тем в научной среде до сих пор отсутствует согласованность о понятиях и сущности приграничной территории. Поэтомув вазличных работах, посвященных приграничному пространству, выбор регионов, которые относятся к нему, а значит и определение его масштабов и структуры, трактуется исходя из объекта исследования. Так, например, В.А. Вашанов в зависимости от уровня правового статуса взаимоотношений России с приграничными государствами предлагает следующую классификацию: «регионы, граничащие со странами так называемого “дальнего зарубежья”..., регионы, граничащие со странами СНГ, регионы, граничащие со странами Таможенного союза СНГ..., регионы, граничащие с Республикой Беларусь...» [5]. Также анализируя правовые вопросы о статусе приграничных территорий, Л.Ф. Балтенкова свидетельствовала, что «многие субъекты Федерации, фактически являющиеся приграничными территориями, юридически этого не закрепляют в своих консти- туциях и уставах» [2]. Классификацию регионов приграничного пространства можно осуществлять по различным признакам, и особое место в таком контексте занимает классификация приграничных регионов, обусловленная геополитическим фактором распада СССР. Одним из первых исследователей, обратившим на это внимание и предложившим свою классификацию, являлся А.Г. Гранберг, разделивший приграничное пространство на регионы с новыми и старыми границами [8]. Позже уточненная классификация регионов приграничья была представлена в статье О.Б. Ангаповой [1]. На основе использования данного подхода Е.П. Сигаревой был проведен сравнительный анализ демографического развития старых и новых приграничных территорий [18]. Отдельные вопросы социально-демографических проблем приграничных территорий рассматриваются не только отечественными специалистами $[3 ; 4 ; 6 ; 7 ; 12 ; 13$; $16 ; 21]$, но и учеными сопредельных стран [9$11 ; 14 ; 17 ; 19 ; 20 ; 24]$. Приграничная территория всегда должна оставаться в центре внимания экспертного сообщества и руководства страны, поэтому вопросы трансформации миг- 
рационных процессов в приграничье за последние 10 лет имеют особую актуальность.

Понятие «приграничье» уже давно вошло в научный оборот $[14 ; 19 ; 20 ; 24]$. А разделение приграничных регионов на «новые» и «старые» обусловлено периодом трансформации границ, когда из административно-территориальных они превратились в государственные, что произошло после распада СССР. По аналогии с «новым» и «старым» зарубежьем, возникшими в силу геополитических изменений в конце XXв. [15], группировка приграничных регионов в данном контексте позволяет раскрыть особенности миграционной ситуации в каждом из этих кластеров.

Научная проблема состоит в возникновении в пределах приграничного пространства демографического дисбаланса с сопредельными странами, что в перспективе формирует риски геополитического характера. Изучение миграционных процессов и их трансформации в российском приграничье в контексте выявления проблем дискретного расселения на рубежах страны и составляло цель данной работы. В качестве гипотезы было выдвинуто следующее положение. Несмотря на одинаковый статус государственной границы, в настоящее время в пределах старых и новых сопредельных к ней территорий происходят различные миграционные процессы, которые приводят к наиболее интенсивной замене населения за счет миграции, именно в новом кластере территорий. Одной из задач исследования была необходимость определить центры концентрации мигрантов как в старом, так и новом приграничье.

В работе использовались методы сравнительного анализа миграционных процессов в регионах старого и нового приграничья, общенаучные методы анализа и группировки, методы структурного анализа, позволившие дифференцировать и обобщить миграционные потоки по отдельным видам миграционного обмена населением. Основные выводы исследования базировались на обобщении статистических данных и выявлении особенностей трансформации миграционной ситуации в регионах приграничья в период между 2008 и 2017 годами.

Общий миграционный прирост регионов старого приграничья в 2008 г. характеризовался отрицательной величиной и составлял чуть более 4 тыс. человек. Заметим, что среди субъектов этой группы насчитывалось 6 территорий с положительным миграционным приростом (табл. 1).

Наиболее крупным миграционным реципиентом в 2008 г. была Ленинградская об-

Таблииа 1

Миграционный прирост регионов старого приграничья за 2008-2017 гг. (чел.)

\begin{tabular}{|c|c|c|c|c|c|c|}
\hline \multirow[b]{2}{*}{$\begin{array}{c}\text { Старые приграничные } \\
\text { субъекты }\end{array}$} & \multicolumn{3}{|c|}{2008 г. } & \multicolumn{3}{|c|}{2017 г. } \\
\hline & $\begin{array}{c}\text { Мигра- } \\
\text { ционный } \\
\text { прирост } \\
\text { всего } \\
\end{array}$ & $\begin{array}{l}\text { с другими } \\
\text { регионами }\end{array}$ & $\begin{array}{c}\text { между- } \\
\text { народных }\end{array}$ & $\begin{array}{c}\text { Мигра- } \\
\text { ционный } \\
\text { прирост } \\
\text { всего } \\
\end{array}$ & $\begin{array}{l}\text { с другими } \\
\text { регионами }\end{array}$ & $\begin{array}{c}\text { между- } \\
\text { народных }\end{array}$ \\
\hline Республика Карелия & 299 & -431 & 730 & -1916 & -1584 & -332 \\
\hline Калининградская область & 3722 & 602 & 3120 & 9839 & 4635 & 5204 \\
\hline Ленинградская область & 13575 & 9166 & 4409 & 30859 & 23463 & 7396 \\
\hline Мурманская область & -7417 & -7956 & 539 & -3503 & -4383 & 880 \\
\hline Республика Алтай & 192 & -20 & 212 & -281 & -218 & -63 \\
\hline Республика Бурятия & -2573 & -2917 & 344 & -3426 & -3137 & -289 \\
\hline Республика Тыва & -2027 & -2091 & 64 & -1055 & -976 & -79 \\
\hline Забайкальский край & -3621 & -4296 & 675 & -7974 & -7614 & -360 \\
\hline Приморский край & -921 & -3354 & 2433 & -5591 & -4946 & -645 \\
\hline Хабаровский край & 706 & -1333 & 2039 & -3690 & -4153 & 463 \\
\hline Амурская область & -3278 & -3447 & 169 & -2104 & -3252 & 1148 \\
\hline Сахалинская область & -2893 & -3731 & 838 & 2373 & -42 & 2415 \\
\hline Еврейская автономная область & 128 & 31 & 97 & -1943 & -1953 & 10 \\
\hline Итого & -4108 & -19777 & 15669 & 11588 & -4160 & 15748 \\
\hline
\end{tabular}

Примечание. Рассчитано по: [22; 23]. 
ласть, куда прибыло более 13,5 тыс. человек. Калининградская область приросла в 2008 г. за счет миграционного прироста примерно на 3,7 тыс. человек. Также Хабаровский край в 2008 г. отмечен положительными показателями миграционного прироста.

В трех остальных субъектах за счет миграции население увеличилось в пределах нескольких сотен человек. Напротив, среди миграционных доноров в группе регионов старого приграничья выделялась Мурманская область, утратившая в обмене населением в 2008 г. более 7 тыс. человек. Другие же регионы старого приграничья «потеряли» в миграционном обмене от 1 до 3,6 тыс. человек. Отметим также, что за редким исключением (Ленинградская область, Калининградская область и Еврейская автономная область) в группе старых приграничных субъектов в 2008 г. общий отрицательный баланс был обусловлен оттоком населения в процессе внутренней миграции, величина которого составила около 20 тыс. человек. Среди регионов старого пограничья Мурманская область в 2008 г. являлась главным «поставщиком» населения в другие регионы России, отрицательный миграционный отток из которой составлял более $40 \%$ общего оттока данной группы территорий.

Все субъекты старого приграничья в 2008 г. были привлекательны для переселения туда внешних мигрантов. Во всех территориях отмечен положительный миграционный прирост за счет международной миграции, совокупная величина которого составила около 15,7 тыс. человек. Однако наибольший миграционный прирост за счет внешней миграции был отмечен в Ленинградской и Калининградской областях, несколько меньше в Хабаровском крае и Амурской области. Таким образом, в 2008 г. среди субъектов старого приграничья наметились два центра миграционного притяжения - это в первую очередь Ленинградская область, во вторую Калининградская область, в которых население прирастало за счет миграции как из других регионов России, так и за счет внешних мигрантов. Мурманская область, наоборот, наиболее активно утрачивала население, отдавая его в другие регионы страны, и даже небольшой миграционный прирост за счет международной миграции не смог изменить характер миграционного тренда.

В 2017 г. миграционная ситуация в регионах старого приграничья изменилась. Во-первых, резко сократилось число регионов, в которых общий миграционный прирост являлся положительным. Только три субъекта в этой группе увеличивают населения за счет миграции: Ленинградская область, Калининградская область и Сахалинская область. Во-вторых, в обмене населением с другими регионами России продолжили оставаться центрами миграционного притяжения Ленинградская и Калининградская области. Они, кстати, и в 2008 г. являлись наиболее мощными реципиентами и внешних мигрантов. В-третьих, международный обмен населением с регионами старого приграничья перестал быть однородным. Обозначились территории, теряющие население как за счет внутренних, так и за счет внешних мигрантов. Это Республика Алтай, Республика Бурятия, Республика Тыва, Забайкальский край и Приморский край. Таким образом, в настоящий период в группе старых приграничных территорий продолжает происходить концентрация мигрантов в отдельных центрах (Ленинградская и Калининградская области) за счет внутренних и внешних миграционных процессов. В других субъектах данной группы (Мурманская область, Хабаровский край, Амурская область, Еврейская автономная область), если и отмечено положительное миграционное сальдо за счет внешних мигрантов, то его величина не перекрывает отток населения в другие регионы России. В Сахалинской области сменился миграционный тренд. В настоящий период она стала миграционным реципиентом за счет резкого сокращения убыли населения в другие регионы России и увеличения прироста международной миграции. А Республика Карелия наоборот, стала миграционным донором за счет увеличения оттока населения (в 3 раза) в другие регионы страны и изменения притока международных мигрантов на отток. Остальные территории старого приграничья характеризуются в настоящий период оттоком населения и в межрегиональной и международной миграции. Общий положительный результат миграционного сальдо по группе регионов старого приграничья, составляющий в 
2017 г. 11,6 тыс. человек, обусловлен лишь положительными последствиями миграционного обмена трех субъектов (Ленинградской, Калининградской и Сахалинской областей), чей миграционный прирост позволил лишь на 26 \% перекрыть отток населения из других субъектов старого приграничья.

Что касается регионов нового приграничья, то следует заметить, что трансформация миграционных процессов здесь еще более выражена. Во-первых, к этой группе присоединились два субъекта: Республика Крым и г. Севастополь, чьи миграционные процессы следует учитывать при анализе произошедших изменений миграционных трендов.
Во-вторых, в отличие от группы регионов старого приграничья, в группе регионов нового приграничья в 2008 г. был зафиксирован значительный положительный прирост населения около 51 тыс. человек (табл. 2).

В этот период число территорий, являющихся миграционными реципиентами, составляло 14. То есть больше половины территорий нового приграничья в 2008 г. пополнялись за счет миграционных процессов. Наибольший миграционный прирост был отмечен в Краснодарском крае, Белгородской, Самарской и Новосибирской областях. Наибольшее отрицательное миграционное сальдо было свойственно Республике Дагестан. В 7-ми субъектах нового

Миграционный прирост регионов нового приграничья за 2008-2017 гг. (чел.)

\begin{tabular}{|c|c|c|c|c|c|c|}
\hline \multirow[b]{2}{*}{ Новые приграничные субъекты } & \multicolumn{3}{|c|}{2008} & \multicolumn{3}{|c|}{2017} \\
\hline & $\begin{array}{c}\text { Мигра- } \\
\text { ционный } \\
\text { прирост } \\
\text { всего }\end{array}$ & $\begin{array}{c}\text { с другими } \\
\text { региона- } \\
\text { ми }\end{array}$ & $\begin{array}{c}\text { между- } \\
\text { народ- } \\
\text { ных }\end{array}$ & $\begin{array}{c}\text { Мигра- } \\
\text { ционный } \\
\text { прирост } \\
\text { всего }\end{array}$ & $\begin{array}{c}\text { с другими } \\
\text { региона- } \\
\text { ми }\end{array}$ & $\begin{array}{c}\text { между- } \\
\text { народ- } \\
\text { ных }\end{array}$ \\
\hline Белгородская область & 11173 & 4395 & 6778 & 2839 & -832 & 3671 \\
\hline Брянская область & 63 & -2238 & 2301 & -2478 & -3865 & 1387 \\
\hline Воронежская область & 5504 & 1182 & 4322 & 10110 & -11 & 10121 \\
\hline Курская область & 1747 & -1070 & 2817 & -988 & -3058 & 2070 \\
\hline Смоленская область & 301 & -1467 & 1768 & 2253 & -2900 & 5153 \\
\hline Псковская область & -760 & -1757 & 997 & -548 & -1375 & 827 \\
\hline Республика Дагестан & -9814 & -10048 & 234 & -12716 & -12509 & -207 \\
\hline Республика Ингушетия & 934 & 844 & 90 & 1233 & 1362 & -129 \\
\hline Кабардино-Балкарская Республика & -2906 & -3224 & 318 & -2397 & -2931 & 534 \\
\hline Республика Калмыкия & -2918 & -2973 & 55 & -2680 & -2630 & -50 \\
\hline Карачаево-Черкесская Республика & -1857 & -2063 & 206 & -960 & -1177 & 217 \\
\hline Республика Северная Осетия & -2655 & -4374 & 1719 & -3271 & -4303 & 1032 \\
\hline Чеченская Республика & -1038 & -1115 & 77 & -2749 & -3417 & 668 \\
\hline Краснодарский край & 30615 & 18661 & 11954 & 34942 & 28573 & 6369 \\
\hline Астраханская область & 390 & -1143 & 1533 & -2002 & -3814 & 1812 \\
\hline Волгоградская область & -1470 & -4730 & 3260 & -5860 & -9022 & 3162 \\
\hline Ростовская область & 5351 & -991 & 6342 & 1907 & -2989 & 4896 \\
\hline Оренбургская область & -3515 & -8607 & 5092 & -8479 & -10437 & 1958 \\
\hline Саратовская область & 888 & -3993 & 4881 & -6160 & -7810 & 1650 \\
\hline Самарская область & 9898 & 2715 & 7183 & -881 & -5357 & 4476 \\
\hline Курганская область & -4078 & -5631 & 1553 & -5113 & -6035 & 922 \\
\hline Тюменская область & 5185 & -5253 & 10438 & 9102 & -3266 & 12368 \\
\hline Челябинская область & 5437 & 121 & 5316 & -3840 & -7346 & 3506 \\
\hline Алтайский край & -4946 & -8212 & 3266 & -8059 & -9299 & 1240 \\
\hline Новосибирская область & 9488 & 5374 & 4114 & 10676 & 1184 & 9492 \\
\hline Омская область & -93 & -3011 & 2918 & -9853 & -11021 & 1168 \\
\hline Республика Крым & & & & 8276 & 1136 & 7140 \\
\hline г. Севастополь & & & & 8733 & 5942 & 2791 \\
\hline Итого & 50924 & -38608 & 89532 & 11037 & -77207 & 88244 \\
\hline
\end{tabular}


приграничья был зафиксирован положительный миграционный тренд с другими регионами России, среди которых также можно выделить Краснодарский край. И напротив, Республика Дагестан наиболее активно утрачивала население в обмене с другими регионами страны. В целом же в данной группе внутрироссийский миграционный обмен характеризовался оттоком населения, который составил в 2008 г. более 38,6 тыс. человек. Этот отток в регионах нового приграничья компенсировал в 2,3 раза превосходящий миграционный прирост международной миграции, который был свойственен всем территориям из этой группы. Его совокупная величина в 2008 г. составила более 89,5 тыс. человек. Наиболее активно международные мигранты прибывали в Краснодарский край и Тюменскую область. Таким образом, за счет двух источников миграции (внутрироссийской и международной) увеличилась численность населения 7 субъектов из данной группы: Белгородской, Воронежской, Самарской, Челябинской, Новосибирской областей, Республики Ингушетия и Краснодарского края.

За счет превышения миграционного прироста внешних мигрантов над оттоком внутрироссийских мигрантов увеличилось население в 2008 г. в Брянской, Курской, Смоленской, Астраханской, Ростовской Саратовской и Тюменской областях. А в остальных субъектах нового приграничья в 2008 г. положительный миграционный прирост международной миграции не смог перекрыть отток населения в другие регионы России.

К 2017 г. в группе новых приграничных регионов уменьшилось число субъектов, где наблюдался положительный миграционный прирост. Если не учитывать Республику Крым и г. Севастополь, то таких территорий осталось 8. Миграционный прирост населения попрежнему свойственен Краснодарскому краю, Новосибирской, Воронежской, Смоленской и Тюменской областям, Республике Ингушетия, которые значительно увеличили миграционный прирост населения. В Белгородской и Ростовской областях положительный миграционный прирост если и сохранился, то уменьшился. В остальных субъектах нового приграничья, которые в 2008 г. имели положительный миграционный баланс, к 2017 г. он сменился на отрицательный. То есть отток населения из нового приграничья усилился. В результате в 2017 г., если не учитывать Республику Крым и г. Севастополь, общим итогом миграционного сальдо стал показатель с отрицательным значением 5972 человек.

Исключая данные по Республике Крым и г. Севастополю, в которых в 2017 г. отмечен положительный миграционный баланс как в общем, так и в отношении внутрироссийской и международной миграции, можно свидетельствовать, что к настоящему периоду в новом приграничье сократилось число (до 3) регионов, имеющих положительный миграционный результат в обмене с другими регионами России. Это Краснодарский край, Новосибирская область и Республика Ингушетия. Все остальные территории нового приграничья являются донорами в межрегиональном обмене населением. Наиболее крупные доноры - Республика Дагестан, Омская, Оренбургская области, Алтайский край, Волгоградская область. В качестве результата межрегиональных миграций новое приграничье имеет в 2017 г. отток населения в размере более 84 тыс. человек. И только благодаря Республике Крым и г. Севастополю он уменьшился до 77 тысяч.

В 2017 г. среди территорий нового приграничья появились и те, в которых наметился миграционный отток и в отношении международной миграции. Это Республика Дагестан, Республика Ингушетия и Республика Калмыкия. Пока международная миграция в целом является существенным источником пополнения населения регионов нового приграничья. Миграционный приток из-за рубежа сохраняется в пределах 88 тыс. человек. Эта цифра указана с учетом Республики Крым и г. Севастополя. Без них миграционный прирост международных мигрантов относительно 2008 г. сократился до 77 тыс. человек. Основные регионы нового приграничья, куда направлялись международные мигранты в 2017 г., были Тюменская, Воронежская, Новосибирская области, Республика Крым и Краснодарский край, который резко сократил прием внешних мигрантов.

\section{Выводы}

Миграционная трансформация в старых приграничных регионах заключается в сокра- 
щении их числа, где происходит прирост населения за счет мигрантов.

В группе регионов старого приграничья выявлены постоянные центры миграционного притяжения: Ленинградская и Калининградская области, численность населения которых продолжает увеличиваться за счет международных и внутрироссийских мигрантов. Причем в настоящий период происходит значительное усиление потока в эти центры внутренних мигрантов.

Ряд старых приграничных регионов Сибири и Дальнего Востока (Республика Алтай, Республика Бурятия, Республика Тыва, Забайкальский край и Приморский край) в настоящее время стали терять население не только в межрегиональном, но и международном миграционном обмене.

Группу регионов нового приграничья к 2017 г. пополнили Республика Крым и г. Севастополь, которые в настоящий период активно заселяются мигрантами из других регионов России и из других государств.

В новом приграничье в настоящее время также существуют центры миграционного притяжения, безусловный статус которых принадлежит Краснодарскому краю и Новосибирской области, в которых продолжает быть положительным миграционный обмен населением как с другими регионами России, так и другими странами.

Без учета Республики Крым и г. Севастополя общий миграционный прирост в группе регионов нового приграничья характеризуется отрицательной величиной. За исключением ряда субъектов данной группы новое приграничье стало утрачивать население. Особенно это выражено в отношении миграционного обмена с другими регионами России.

В целом можно сказать, что в российском приграничье продолжается процесс концентрации населения в отдельных субъектах. Другие же охвачены утратой населения из-за миграционных процессов или активным «замещением» отечественного населения зарубежными мигрантами. В перспективе это обусловливает «разрыв» традиционной приграничной полосы заселения и создаст значительные геополитические риски.

\section{СПИСОК ЛИТЕРАТУРЫ}

1. Ангапова, О. Б. Классификация приграничных регионов Российской Федерации / О. Б. Ангапова // Вестник Бурятского государственного университета. - 2014. - № 2. - С. 76-80.

2. Балтенкова, Л. Ф. Российский федерализм и правовые проблемы приграничных территорий / Л. Ф. Балтенкова. - Электрон. текстовые дан. Режим доступа: http://www.mininform.orb.ru/books/ prigr/boltenk.htm. - Загл. с экрана.

3. Баскакова, И. А. Перспективы развития приграничного сотрудничества России и Казахстана в рамках Таможенного союза / И. А. Баскакова // Вестник РГГУ. Серия: Политология. История. Международные отношения. Зарубежное регионоведение. Востоковедение. - 2013. - № 21 (122). C. $186-195$.

4. Белокоскова, Е. Е. Приграничное сотрудничество как фактор интеграции экономики стран ЕВРаЗЕС / Е. Е. Белокоскова // Проблемы современной экономики. - 2003. - № 2 (6). - С. 27-30.

5. Вашанов, В. А. Совершенствование производственно-хозяйственных связей регионов России и СНГ / В. А. Вашанов. - Электрон. текстовые дан. - Режим доступа: http://www.mininform.orb.ru/ books/prigr/vash.htm. - Загл. с экрана.

6. Верхутина, М. В. Роль гуманитарного сотрудничества в развитии интеграции приграничных регионов стран «славянского треугольника» СНГ / М. В. Верхутина // Среднерусский вестник общественных наук. - 2008. - № 3 (8). - С. 90-93.

7. Главное средство защиты рубежа - обустройство жизни населения. - Электрон. текстовые дан. - Режим доступа: http://glazychev.ru/ publications/interviews/2006_interview_glavnoe _sredstvo_zaschity_rubezha_obustroistvo.htm. Загл. с экрана.

8. Гранберг, А. Г. Основы региональной экономики : учеб. для вузов / А. Г. Гранберг. - М. : ГУ ВШЭ, 2000. $-495 \mathrm{c}$.

9. Кирюхин, А. М. Развитие приграничного сотрудничества между Украиной и Российской Федерацией в контексте общеевропейской интеграции / А. М. Кирюхин // Евразийская экономическая интеграция. - 2012. - № 4 (17). - С. 121-127.

10. Лу, Ч. Понятие приграничного сотрудничества в исторической ретроспективе (по китайским и российским источникам) / Ч. Лу // Актуальные проблемы развития КНР в процессе ее регионализации и глобализации : сб. ст. VIII Междунар.практ. конф., 10 марта 2016 г., г. Чита. - Чита : Изд-во Забайкал. гос. ун-та, 2016. - С. 155-164.

11. Никитенко, П. Белорусско-российское приграничное сотрудничество как фактор формирования союзного государства Беларуси и России 
/ П. Никитенко, Т. Вертинская // Общество и экономика. - 2006. - № 3. - С. 86-99.

12. Павлов, П. В. Приграничная торговля как часть приграничного сотрудничества России с иностранными государствами: проблемы административно-правового регулирования / П. В. Павлов // NB: Административное право и практика администрирования. - 2013. - № 2. - С. 1-71.

13. Плотникова, О.В.Приграничное сотрудничество регионов государств как основа укрепления двусторонних международных отношений (на примере российско-китайского приграничного сотрудничества) / О. В. Плотникова // Сибирский международный. - 2016. - № 18. - С. 58-62.

14. Правовая культура молодежи приграничья России и Беларуси / Л. Н. Николаева, А. А. Бочков, В. Г. Стаценко, А. А. Сухарев. - Смоленск : Универсум, 2011. $-242 \mathrm{c}$.

15. Рыбаковский, Л. Л. Россия и новое зарубежье: миграционный обмен и его влияние на демографическую политику / Л. Л. Рыбаковский. - М. : ИСПИ РАН, 1996. - 55 с.

16. Сапрыка, В. А. Сценарии развития приграничного и межрегионального взаимодействия регионов союзного государства Российской Федерации и Республики Беларусь / В. А. Сапрыка // Среднерусский вестник общественных наук. - 2016. T. 11, № 6. - С. 405-410.

17. Сдыков, М. Н. Казахстан и Россия в системе приграничных миграций // Россия - Казахстан: фронтьерские миграции : сб. науч. тр. / М. Н. Сдыков ; под общ. ред. Ж. А. Зайончковской и М. Н. Сдыкова. - М. ; Уральск, 2002. - С. 7-41.

18. Сигарева, Е. П. Демографические процессы в приграничных районах Российской Федерации / Е. П. Сигарева // Национальная идентичность России и демографический кризис : материалы II Всерос. науч. конф. (15 нояб. 2007 г.). - М. : Науч. эксперт, 2008. - С. 92-108.

19. Слемнев, М. А. Белорусско-российское приграничье как социокультурный феномен / М. А. Слемнев, И. М. Слемнев // Беларусь и Россия в европейском контексте: проблемы государственного управления процессом модернизации : материалы Междунар. науч.-практ. конф., г. Минск, 20-21 окт. 2011 г. Минск : Право и экономика, 2011. - С. 310-313.

20. Слемнев, М. А. Белорусско-российское приграничье: от геотрионной модели к социокультурной презентации / М. А. Слемнев // От Киевской Руси до России XXI века: вехи российской истории, государственности, общества и культуры : материалы Междунар. науч. конф., посвящ. 1150-летию Российской государственности, 24-25 мая 2012 г. - Витебск : Учреждение образования федерации профсоюзов Беларуси «Международный университет "МИТСО”», 2012. - С. 247-251.
21. Уханкин, В. В. Приграничное сотрудничество как механизм интеграции государств (постановка вопроса) / В. В. Уханкин // Вопросы национальных и федеративных отношений. - 2012. № 2 (17). - С. 155-159.

22. Численность и миграция населения Российской Федерации в 2008 г. - Электрон. текстовые дан. - Режим доступа: http://www.gks.ru/bgd/regl/ B09_107/Main.htm. - Загл. с экрана.

23. Численность и миграция населения Российской Федерации в 2017 г. - Электрон. текстовые дан. - Режим доступа: http://www.gks.ru/bgd/regl/ b18_107/Main.htm. - Загл. с экрана.

24. Янчук, В. А. Формирование союзного государства как фактор развития приграничного белорусско-российского сотрудничества / В. А. Янчук // Состояние и перспективы развития белорусско-российского приграничья как специфической социокультурной реальности : материалы Междунар. науч.-практ. конф., г. Витебск, 26-27 нояб. 2013 г. - Витебск, 2013. - С. 130-132.

\section{REFERENCES}

1. Angapova O.B. Klassifikatsiya prigranichnykh regionov Rossiyskoy Federatsii [Classification of Border Regions of the Russian Federation]. Vestnik Buryatskogo Gosudarstvennogo universiteta, 2014, no. 2, pp. 76-80.

2. Baltenkova L.F. Rossiyskiy federalizm $i$ pravovye problemy prigranichnykh territoriy [Russian federalism and legal problems of border areas]. URL: http://www.mininform.orb.ru/books/prigr/ boltenk.htm.

3. Baskakova I.A. Perspektivy razvitiya prigranichnogo sotrudnichestva Rossii i Kazakhstana v ramkakh Tamozhennogo soyuza [Prospects for the Development of Cross-border Cooperation between Russia and Kazakhstan in the Framework of the Customs Union]. Vestnik RGGU. Seriya: Politologiya. Istoriya. Mezhdunarodnye otnosheniya. Zarubezhnoe regionovedenie. Vostokovedenie, 2013, no. 21 (122), pp. 186-195.

4. Belokoskova E.E. Prigranichnoe sotrudnichestvo kak faktor integratsii ekonomiki stran EVRaZES [Crossborder Cooperation as a Factor in the Integration of the Economies of the Countries of EurAsEC]. Problemy sovremennoy ekonomiki, 2003, no. 2 (6), pp. 27-30.

5. Vashanov V.A. Sovershenstvovanie proizvodstvenno-khozyaystvennykh svyazey regionov Rossii i $S N G$ [Improvement of Production and Economic Relations of the Regions of Russia and the CIS]. URL: http://www.mininform.orb.ru/books/ prigr/vash.htm. 
6. Verkhutina M.V. Rol gumanitarnogo sotrudnichestva $\mathrm{v}$ razvitii integratsii prigranichnykh regionov stran «slavyanskogo treugolnika» SNG [The Role of Humanitarian Cooperation in the Development of Integration of the Border Regions of the Countries of the "Slavic Triangle" of the CIS]. Srednerusskiy vestnik obshchestvennykh nauk, 2008, no. 3 (8), pp. 90-93.

7. Glavnoe sredstvo zashchity rubezhaobustroystvo zhizni naseleniya [The Main Means of Protecting the Border is the Living Arrangement of the Population]. URL: http:/glazychev.ru/publications/ interviews/2006_interview_glavnoe_sredstvo_ zaschity_rubezha_obustroistvo.htm.

8. Granberg A.G. Osnovy regionalnoy ekonomiki: ucheb. dlya vuzov [Fundamentals of the Regional Economy: a Textbook for Universities]. Moscow, GU VSHE Publ., 2000. 495 p.

9. Kiryukhin A.M. Razvitie prigranichnogo sotrudnichestva mezhdu Ukrainoy i Rossiyskoy Federatsiey v kontekste obshcheevropeyskoy integratsii [Development of Cross-border Cooperation between Ukraine and the Russian Federation in the Context of European Integration]. Evraziyskaya ekonomicheskaya integratsiya, 2012, no. 4 (17), pp. 121-127.

10. Lu Ch. Ponyatie prigranichnogo sotrudnichestva $\mathrm{v}$ istoricheskoy retrospektive (po kitayskim i rossiyskim istochnikam) [The Concept of Cross-border Cooperation in a Historical Retrospective (According to Chinese and Russian Sources)]. Aktualnye problemy razvitiya KNR v protsesse ee regionalizatsii i globalizatsii: sb. st. VIII Mezhdunar. nauch.-prakt. konf., Chita, 2016, pp. 155-164.

11. Nikitenko P., Vertinskaya T. Belorusskorossiyskoe prigranichnoe sotrudnichestvo kak faktor formirovaniya soyuznogo gosudarstva Belarusi i Rossii [Belarusian-Russian Border Cooperation as a Factor in the Formation of the Union State of Belarus and Russia]. Obshchestvo i ekonomika, 2006, no. 3, pp. 86-99.

12. Pavlov P.V. Prigranichnaya torgovlya kak chast prigranichnogo sotrudnichestva Rossii s inostrannymi gosudarstvami: problemy administrativno-pravovogo regulirovaniya [Cross-border Trade as Part of Crossborder Cooperation between Russia and Foreign Countries: Problems of Administrative and Legal Regulation]. NB: Administrativnoe pravo i praktika administrirovaniya, 2013, no. 2, pp. 1-71.

13. Plotnikova O.V. Prigranichnoe sotrudnichestvo regionov gosudarstv kak osnova ukrepleniya dvustoronnikh mezhdunarodnykh otnosheniy (na primere rossiysko-kitayskogo prigranichnogo sotrudnichestva) [Cross-border Cooperation between Regions of States as a Basis for Strengthening Bilateral International Relations (on the Example of RussianChinese Cross-border cooperation)]. Sibirskiy mezhdunarodnyy, 2016, no. 18, pp. 58-62.
14. Nikolayeva L.N., Bochkov A.A., Statsenko V.G., Sukharev A.A. Pravovaya kultura molodezhi prigranichya Rossii i Belarusi [Legal Culture of Youth in the Border Areas of Russia and Belarus]. Smolensk, Universum, 2011. 242 p.

15. Rybakovskiy L.L. Rossiya $i$ novoe zarubezhye: migratsionnyy obmen i ego vliyanie na demograficheskuyu politiku [Russia and the New Abroad: Migration Exchange and its Impact on Demographic Policy]. Moscow, ISPI RAN Publ., 1996. $55 \mathrm{p}$.

16. Sapryka V.A. Stsenarii razvitiya prigranichnogo i mezhregionalnogo vzaimodeystviya regionov soyuznogo gosudarstva Rossiyskoy Federatsii i Respubliki Belarus [Scenarios of Development of Cross-border and Interregional Interaction of the Regions of the Union State of the Russian Federation and the Republic of Belarus]. Srednerusskiy vestnik obshchestvennykh nauk, 2016, vol. 11, no. 6, pp. 405-410.

17. Sdykov M.N. Kazakhstan i Rossiya v sisteme prigranichnykh migratsiy [Kazakhstan and Russia in the System of Border Migration]. Zayonchkovskoy Zh.A., Sdykova M.N., eds. Rossiya - Kazakhstan: fronterskiye migratsii: sb. nauch. tr. Moscow, Uralsk, 2002, pp. 7-41.

18. Sigareva E.P. Demograficheskie protsessy v prigranichnykh rayonakh Rossiyskoy Federatsii [Demographic Processes in the Border Regions of the Russian Federation]. Natsionalnaya identichnost Rossii i demograficheskiy krizis: materialy II Vseros. nauch. konf. Moscow, Nauchnyy ekspert Publ., 2008, pp. 92-108.

19. Slemnev M.A., Slemnev I.M. Belorusskorossiyskoe prigranichye kak sotsiokulturnyy fenomen [Belarusian-Russian Border Region as a Socio-cultural Phenomenon]. Belarus $i$ Rossiya $v$ evropeyskom kontekste: problemy gosudarstvennogo upravleniya protsessom modernizatsii: materialy Mezhdunar. nauch.-prakt. konf., g. Minsk, 20-21 okt. 2011 g. Minsk, 2011,pp. 310-313.

20. Slemnev M.A. Belorussko-rossiyskoe prigranichye: ot geotrionnoy modeli $\mathrm{k}$ sotsiokulturnoy prezentatsii [Belarusian-Russian Border Region: from a Geotrion Model to a Sociocultural Presentation]. Ot Kievskoy Rusi do Rossii XXIveka: vekhi rossiyskoy istorii, gosudarstvennosti, obshchestva i kultury: materialy Mezhdunar. nauch. konf., posvyash. 1150-letiyu Rossiyskoy gosudarstvennosti, 24-25 maya $2012 \mathrm{~g}$. Vitebsk, 2012, pp. 247-251.

21. Ukhankin V.V. Prigranichnoe sotrudnichestvo kak mekhanizm integratsii gosudarstv (postanovka voprosa). Voprosy natsionalnykh $i$ federativnykh otnosheniy [Cross-border Cooperation as a Mechanism for the Integration of States (Posing the Question)], 2012, no. 2(17), pp. 155-159. 
22. Chislennost i migratsiya naseleniya Rossiyskoy Federatsii v $2008 \mathrm{~g}$. [The Number and Migration of the Population of the Russian Federation in 2008]. URL: http://www.gks.ru/bgd/regl/B09_107/ Main.htm.

23. Chislennost i migratsiya naseleniya Rossiyskoy Federatsii v 2017 g. [Population Size and Migration in the Russian Federation in 2017]. URL: http://www.gks.ru/bgd/regl/b18_107/Main.htm.
24. Yanchuk V.A. Formirovanie soyuznogo gosudarstva kak faktor razvitiya prigranichnogo belorussko-rossiyskogo sotrudnichestva [Formation of a Union State as a Factor in the Development of Belarusian-Russian Border Cooperation]. Sostoyanie $i$ perspektivy razvitiya belorussko-rossiyskogo prigranichya kak spetsificheskoy sotsiokulturnoy realnosti: materialy Mezhdunar. nauch.-prakt. konf., Vitebsk, 2013,pp. 130-132.

\section{Information about the Author}

Dmitriy P. Maevskiy, Candidate of Economic Sciences, First Vice-Rector, Omsk State Technical University, Prosp. Mira, 11, 644050 Omsk, Russian Federation, maevskiydp@gmail.com, https://orcid.org/ 0000-0003-0533-7609

\section{Информация об авторе}

Дмитрий Павлович Маевский, кандидат экономических наук, доцент, первый проректор, Омский государственный технический университет, просп. Мира, 11, 644050 г. Омск, Российская Федерация, maevskiydp@gmail.com, https://orcid.org/0000-0003-0533-7609 